\title{
The Importance of Ferdinand Augustin Hallerstein for Cultural and Political Relations with China and Korea
}

\author{
Mitja SAJE*
}

\begin{abstract}
Since symbols of early cultural relations between Europe and East Asia are important, we are striving to restore the image of Augustin Hallerstein (1703-1774) in China and earn his legacy its appropriate position in the history of the Qing dynasty next to other great Jesuits like Adam Shall von Bell (1591-1666), Ferdinand Verbiest (1623-1688), or Ignatius Kögler (1680-1746). A two-year EU project made possible the publication of a monograph in English, which was translated into Chinese and published in China in February 2015. Wider popularization of his achievements should be beneficial to Slovenia as well as to China, where he did his work. Such common heroes of the past could often be used to promote better understanding and cooperation between China and Slovenia. Through strong connections with Korean scholars he gained a high reputation in Korea as well.
\end{abstract}

Keywords: Hallerstein, Qing dynasty, Jesuits, astronomy, science

\section{Izvleček}

Zaradi pomembnosti, ki jo imajo simboli zgodnjih kulturnih stikov med Evropo in vzhodno Azijo, si prizadevamo obuditi podobo Avguština Hallersteina (1703-1774) v skladu s položajem, ki ga je dosegel na Kitajskem, ter mu zagotoviti primerno mesto v zgodovini dinastije Qing ob boku drugih najpomembnejših jezuitov, kot so bili Adam Shall von Bell (1591-1666), Ferdinand Verbiest (1623-1688) ali Ignatius Kögler (1680-1746). Dve letni EU projekt je omogočil izdajo angleške monografije, ki so jo leta 2015 prevedli in izdali na Kitajskem. Širša odmevnost njegovih dosežkov je pomembna tako za Slovenijo kot za Kitajsko. Taki skupni junaki preteklosti so lahko pogosto v pomoč za boljše medsebojno razumevanje in sodelovanje med Kitajsko in Slovenijo. Podobno bi lahko veljalo tudi za Korejo, ker si je Hallerstein v sodelovanju z njihovimi učenjaki pridobil velik ugled tudi v Koreji.

Ključne besede: Hallerstein, dinastija Qing, jezuiti, astronomija, znanost

Mitja SAJE, Professor, Department of Asian Studies,

Faculty of Arts, University of Ljubljana, Slovenia.

mitjasaje@hotmail.com

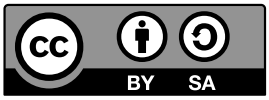




\section{Introduction}

Historic symbols of cultural connections and good relations are becoming even more important in contemporary society. It may be said that Slovenia is very lucky to have a prominent figure-Ferdinand Augustin Hallerstein (1703-1774)functioning in early European-Chinese relations. The problem is that he has been almost forgotten, so we had to rediscover him and restore his appropriate historic position, though his importance as a symbol of early cultural relations with China is still not adequately recognised. Because such symbols are equally important for both sides involved our efforts were also dedicated to restoring his image in China and earn him his appropriate position in Qing dynasty history. However, based on recent research into his activities in Beijing we are discovering his strong connections with Korean scholars and further that through the writings in the Korean books of one of his admirers, Hallerstein gained a great reputation in Korea and even became a rather well-known scientist. Based on these new discoveries we can extend Hallerstein's symbolic importance to Korea so that he can figure as a symbolic cultural link not only between China and Slovenia, but also between Korea and Slovenia. When the awareness of such a common historic cultural symbol is well-established, then politics can come in and exploit the mutually recognised historic facts to the benefit of better relations between two countries.

The Jesuit missionary Ferdinand Augustin Haller von Hallerstein, Chinese name Liu Songling 劉松齡, held a remarkable position in Beijing acting as the head of The Imperial Board of Astronomy from 1746 until his death in 1774. Until very recently there was still very little known about his historic role as a cultural link between Europe and China and even less about his Korean connections. On the other side there was only a rough awareness in limited scientific circles of his contribution in the development of Western and Chinese science. In light of his achievements he could well be placed among the most celebrated Jesuits working in the Qing dynasty China such as Adam Schall von Bell (1591-1666), Ferdinand Verbiest (1623-1688), or Ignatius Kögler (1680-1746), but due to certain historic reasons connected with Hallerstein's native place he is far less-known and we can hardly find his name in most important books in either Western sinology or in history books in China. For these reasons it was our duty to rediscover him and place him next to the above-mentioned Jesuit missionaries working in China and to assure his appropriate position in sinological circles, as well as among historians and the general population both in Slovenia and in China.

One of the reasons for Hallerstein's historic oblivion was the fact that he was born in Carniola, the Austrian province with a Slovenian population, which after World War I became part of the Kingdom of Serbs, Croats, and Slovenes, later 
Yugoslavia, and is now part of the Republic of Slovenia. It is evident that after the collapse of the Austrian Empire there was not much motivation in Austria to research the activities regarding his missionary work in China. Apart from the Jesuit community and some historians of science, who kept records of his purely scientific achievements, he was almost unknown in European sinological circles. Though some of his letters were published in German in the Jesuit publication Welt-Bott, they did not attract much attention since his figure was little known. In Europe almost no other materials were published and no comprehensive documentation regarding his life and work in China was available, because different documents, scientific reports, and letters were scattered in archives in several European countries (Austria, Italy and the Vatican, Portugal, Russia, France, England, Belgium, and Slovenia).

\section{Rediscovering Hallerstein's Historic Role}

Even in Slovenia until recently Hallerstein was little known to the general public. Though having been a prominent scientist of the 18th century, not to mention his cultural mission to China, only some workers in archives kept records of him until Dr Zmago Šmitek, Professor of non-European ethnology and cultural anthropology at the University of Ljubljana, started a broad study on famous Slovenes who had travelled to distant lands in past centuries. He published his first book regarding this topic in 1986 (Šmitek 1986), in which among many others there was one chapter dedicated to Augustin Hallerstein. Then, in 1995 his second book (Šmitek 1995) followed, in which he published a comprehensive study of Hallerstein's biography based on extensive research of European archives. This was the basic study uncovering the importance of Hallerstein's position in China and disclosing the scope of his work as well as stating some comments from his letters concerning his travel and the situation in China. In the meanwhile the Archives of the Republic of Slovenia made their first contacts with their Chinese partners and the cooperation between the two institutions concerning the documents focusing on Hallerstein's sojourn in China has begun. At the same time the first Slovenian ethnologist and anthropologist discovered Hallerstein's tombstone in the Jesuit cemetery in Beijing, ${ }^{1}$ and learned that his Chinese name was Liu Songling. After that we started a systematic search for Chinese documents and other materials concerning his life in Beijing.

1 Ralf Čeplak was the one who first climbed the wall surrounding the restored complex of the Jesuit cemetery. Previously that location had been inaccessible because it was situated in the restricted area of the Beijing Party School. 
As we started researching Hallerstein in China, we discovered that even there he has been almost completely forgotten, the main reasons being the historic circumstances in China in the late 18th century. The changing social environment influenced a new approach towards Jesuits, foreign missionaries, and foreigners in general. In its outward appearance China was still a magnificent empire immersed in its own tradition, blinded by its past glory, but under the surface Chinese traditionalism squeezed under Manchu repression was slowly losing ground in competition with a rapidly modernising world in which the industrial revolution was making a profound impact on societies and the development of nations. This impact was indirectly perceived in China as a complex process of several new circumstances that strongly influenced Chinese historic thinking and perception of the role of foreigners in Chinese history.

To begin with, the Chinese attitude towards Christianity and Christian missionaries drastically changed in the 18th century and was far from the tolerant approach under Emperor Kangxi 康熙 (1654-1722) in the previous century. During the reign of Emperor Qianlong 乾隆 (1711-1799) the missionary work of the Jesuits in China was partly at a disadvantage because of the rigid policy of papal Rome, which did not allow the Jesuits to continue to use their successful accommodation method when preaching Christian religion and partly the missionary activities were under hard pressure from growing Manchu absolutism. The Manchu monarchs in the role of the "Son of Heaven" were adopting the image of cosmopolitan world leaders in every domain from politics to culture and religion and would not accept another religious authority outside their own realm, for example the Pope in Rome. No wonder that tensions arose between Rome and the Chinese court, since Chinese emperors felt that this was Rome's interference in their authority in China. As a response they adopted more strict measures towards Christian religion and the missionary work. As a consequence missionary work was severely limited and occasionally even forbidden and persecuted. The Jesuits were aware of these difficulties and knew that Chinese emperors appreciated them mainly because of their more advanced scientific methods. The Jesuits concentrated on their scientific work in order to win the favour of Emperor Qianlong, who was the main protector of their work, hoping that they would eventually continue their religious work as well. Hallerstein's comment on the Pope's decision was rather stoic. In a letter dated on October 6,1743 , addressed to his brother, he wrote:

You are asking what kind of echo was caused by Pope Benedictus XIVth's decision about Chinese rituals. I am answering that it caused what we have been expecting. We accepted it, promised, and we will keep to it. 
And really we do not have those troubles, because this Chinese Christianity is limited to the very poor, who hardly have enough for food and living, so how could they bring gifts to their ancestors, sacrifice or build houses for them. (Pray 1781, 1: I-XVI)

From this comment we can see how much the situation of missionary work in China had changed since the time of the early Jesuits, when the application of the accommodation method had helped them spread Christianity even among the very rich and high-ranking officials. From then the conditions for missionary work in China changed so much that occasionally even the Jesuits in Peking became the target of prosecution. Hallerstein mentions one such attempt in the letter dated on 28th of November 1749, addressed to his brother, in which he wrote:

Also in Peking they undertook many things against us. The Portuguese Father Felix da Rocha and I even stood before the court of law for having provided Christians with books about our faith, breviaries, devotional pictures, rosaries and similar items. However, the Emperor took up our cause when the judge presented the matter to him. Further: so that the Peking brothers would not be able to help the brothers in the provinces and in communal affairs, they so cunningly sealed off our access to the Emperor, whom we could visit only with difficulty, if at all, meaning that everything that we were planning or attempting has fallen through. We can thus count it as a success that we have maintained this post in Peking at all. (Pray 1781, 2: XVII-XXIX)

Further, a new attitude towards natural sciences and mathematics emerged in China in the 17th century and there was an impression in the 18th century that China was narrowing the gap between the level of science in China and in the West. Because of this impression there was a prevailing perception among later Chinese historians that foreign Jesuit missionaries of the 18th century did not bring any new science to China and so their staying in China was not as important as in earlier times. Such viewpoints were strengthened by the fact that there was strong competition between the Chinese and foreigners in the Imperial Board of Astronomy, where the Chinese scientists envied the leading position of foreigners and often tried to discredit the actions of the Jesuits in order to improve their own positions.

In his letters Hallerstein mentions several attempts by his Chinese collegues to bring European Jesuits into discredit. For example in his 5 th letter to his brother Weichard (1706-1780, also Jesuit, based in Brussels) dated 6 November 1740, he describes attempts by Chinese astronomers to bring the European Jesuits into an 
unfavourable position by making false accusations, and the Emperor's reaction when the Jesuits proved that all the accusations were groundless. He writes:

That it is a thorn in the side of the Chinese astronomers to have to see sitting in the mathematical tribunal also our order members, and this even in high positions, is known. Now they have written a slanderous accusation against us and presented it to the Emperor that he might, if not cast us out of the saddle, at least denigrate us before the people. The contents of the letter were that the Europeans were striving with all their strength to eradicate and destroy the memory of Chinese astronomy, which had flourished since antiquity. To prove this, they cite that Nan Huairen, that is, Father Ferdinand Verbiest, dared to cast into the darkest corner of the observation tower all of the old Chinese well-crafted devices which they had used to advantage for many a year, and in their place set up a new device in the European tradition. That Jilian Yunfeng, that is, Father Kilian Stumpf, went even further when he melted down a few pieces of the aforementioned well-crafted devices, poured them into another model and publicly displayed them in the said place as a sign of the victory of foreign science, as a gibe to the native people. That Dai Jinxian and Xu Maode, that is, Fathers Ignaz Kögler and André Pereira, who were responsible for mathematics, planned nothing less treacherous than zealously to do away with all remaining Chinese antiquity and, by asserting their own newly-established art, to destroy the honour and renown of the science of antiquity that had been valid for many centuries in China, if they were not stopped in time. This document, disseminated in printed form throughout the entire country, immediately fell into the aforementioned Fathers' hands, though these did not hesitate to rebuke it. They sent the Emperor a letter in which they demonstrate that everything that Father Verbiest had done was done on the command of the Emperor Kangxi, meaning that he is being accused of disobedience for carrying out the will of the Emperor, even though he could not do otherwise without being disrespectful, which is indictable. They wrote further that though Father Stumpf did indeed pour the new quadrant, this also occurred at the demand of the court, and it was not from the remains of a destroyed and old device that had been melted down, but from the metal that a mandarin obtained at the Emperor's command, as can be confirmed from the ledger books of that time. That they themselves, Fathers Kögler and Pereira, did not dispel with a single bit of the memory of Chinese antiquity, much less invent something new. Neither could anyone convince them that they ever, with a single word, 
showed or aspired to show that they belittle, reject or even dismantle old and renowned Chinese astrology. The conclusion was that none of the accusations were based on truth, but on the nefarious imputations of their jealous slanderers. The Emperor graciously accepted the defence document. However, this had no other effect than that the accusations fell into oblivion. We do not know whether these despicable slanderers were allotted punishment, nor what punishment there might have been. If they deigned to appear before the Emperor's throne with a document so full of lies, in the time of Emperor Yongzheng they would have paid for their boldness, if not with their heads, then at least with a rather severe punishment. (Welt-Bott IV, 588: 93-97)

In the Library of the Imperial Palace in Taipei I found four documents which are dated the 28th year of Emperor Qianlong and are mainly related to similar circumstances. The documents deal with financial matters concerning some false accusations that the Imperial Board of Astronomy was misusing some funds and disclosing Hallerstein's proofs that the money was spent properly and that all the accusations were groundless. Such biased perception is especially unfair for Hallerstein, because of his outstanding scientific performance. Because of the changed situation in China, it was only for the reason of scientific work that the emperor still kept foreign Jesuits in leading positions on the Imperial Board of Astronomy. Hallerstein obtained his high position on the Imperial Board of Astronomy precisely because of his reputation as a good scientist and excellent mathematician. We can get the information how Hallerstein immediately rose to a prominent position in Beijing from Louis Pfister's description of life and bibliography of Jesuits from the old China mission (Pfister 1934). Pfister wrote that after Hallerstein's arrival in Macao on September 4,1938, the news that he was an excellent mathematician came quickly to Peking, so the next year he was asked to come to Beijing, where the emperor Qianlong became fond of him and ordered him to become the aid of Ignatius Kögler. After Kögler's death, Hallerstein was nominated as his successor as president of the Board of Mathematics upon the recommendation of the Jesuit father Andreas Pereira (1689-1743), who liked him very much and suggested to the emperor that Hallerstein was the most capable to fill that position, in defiance of several Mandarins who wanted to secure this position for a Muslim. Hallerstein held that position for almost thirty years. Further, Pfister wrote that Hallerstein's devotion to exact astronomical observations was part of his character. Pfister quotes the famous French astronomer of the time Antoine Gaubil (1689-1759), who greatly praised Hallerstein in his letters, speaking about his zeal to work. He mentions also the troubles Hallerstein had to endure because of some Chinese and Manchu commissionaires and superintendents who wanted 
to appropriate his achievements and present it as their own merits to further their own promotions... so, not everything was rosy at the Beijing Court, nor was it for the presidents of The Imperial Board of Astronomy.

Though Hallerstein's position in The Imperial Board of Astronomy was not very easy, he maintained an efficient working atmosphere and accomplished many important tasks. Besides calculating the calendar and solar eclipses, which was the usual work of this institution, he helped to design and to install the new armillary sphere with which became the pride of Beijing's astronomic observatory. The emperor's order to construct a new equatorial armillary sphere was issued in 1744 . The project officially started under the supervision of Ignatius Kögler who at that time was already seriously ill and died two years later, so most of the work was carried out by Hallerstein. The armillary sphere was finished in 1754 and is still the most impressive astronomic instrument of the old observatory in Beijing. Connected with the construction of this instrument was the famous astronomic book Astronomical Instruments and Complete Studies by Imperial Order (Osojnik 2003) Qinding yixiangkaocheng 欽定儀象考成, which includes the design of the instrument, the map of stars, and the catalogue of 3083 stars that was published in 1757 and later translated in French (Chevalier 1914). The results of Hallerstein's observations were also published in Europe with the help of Russian diplomat Ivan Kropotov, in a book named Observationes asronomicae, printed in Vienna in 1768. His numerous astronomic observations are well documented in Comentarii of the St. Petersburg Academy of Sciences. Hallerstein's legacy at the Beijing Jesuit Library (now in Capital Library in Beijing) features Stržinar's Slovenian Songbook, printed in 1729 in Graz and taken by Hallerstein to China.

Apart from his regular work Hallerstein even succeeded in carrying out several scientific accomplishments that were not directly linked to his official tasks. He discovered a new comet that appeared in the year 1748 (C 1748 H1) and reported it to the Royal Society in London. To the same institution he provided some herb samples and a description of the musk deer. Then he calculated the geographical length of Beijing from the orbits of Jupiter's satellites on the basis of time difference between Beijing and Saint Petersburg. In the scientific circles of the time he became quite known because of his experiments with inductive electricity. He calculated the total population of China for the year 1760 when the total of 19 provinces was $196,837,977$, and for the year 1761 when its total was 198,214,533. He was actually the first to make such precise calculations. In the field of geography, he made the map of the Mulan region in Manchuria, and took part in preparations for the Big Atlas of China, which the Jesuits published in 1761. In his scientific work he maintained contacts with the Academies in London, Paris and Saint Petersburg, and published his works in different European countries 
as well as in China. In fact Hallerstein did more scientific work and had greater variety of scientific results then most if not all of his predecessors in the Imperial Board of Astronomy, but because of changed historic circumstances in China, his scientific achievements were only praised in Europe and completely forgotten in China. Even Hallerstein himself had the feeling that the emperor valued the work of foreign Jesuits only out of necessity for accurate astronomic calculations, but on the other side Hallerstein was very disappointed with the attitude of Chinese officials, who showed no interest in his experiments with electromagnetic induction.

The third, and probably most important, factor for the later oblivion of Hallerstein and his scientific achievements in China was the immense influence of the Opium Wars and the attitude of imperialistic powers in 19th century China on Chinese historic thinking and the perception of the role of foreigners in Chinese history. China experienced very traumatic times of extortion and humiliation; as a consequence, there was a tendency to blame foreigners for all the misfortunes China had suffered. Gradually a superficial and one-sided view of this part of Chinese history emerged, with strong support from the ruling Communist party and the rigid requirements of its ideology. Under such pressure Chinese historians stopped distinguishing which foreigners did something beneficial for China, and also did not pay much attention to what foreigners' various intentions were or from which specific country each came. As the time span covered by this kind of thinking gradually broadened, it also encompassed the second half of the 18th century, the historical period of which Hallerstein just happened to be part, a period for which Chinese historians did not feel comfortable to write about the activities of foreigners. According to this tendency in Chinese historic writing the attitude towards Christian missionaries from the late Qing dynasty onward was in principle biased with simplified and not very accurate conclusions. There were nonetheless several scholars in China who had better knowledge of historic facts, but due to the prevailing political mood simply did not dare to write about unsuitable topics, or were persecuted when touching upon undesirable themes.

A good example of an unlucky historian who fell from favour because of his research on Jesuit missionaries was Professor Yan Zonglin 閻宗臨 (1904-1978). He was actually the first Chinese scholar to discover sources and to write about Hallerstein, but because of unfortunate political circumstances, he remained forgotten and unnoticed. In 1925 he went to France to study, obtained a Ph.D. in Switzerland in 1936, and was the first Chinese scholar who, because of his knowledge of Latin, went to study the archives in Rome concerning Jesuit missionaries. He was interested in mediaeval world history, European cultural history, and early contacts between China and the West, and in this context in his articles he mentioned Hallerstein and other Jesuit missionaries. Being a patriot 
he returned to his homeland after the Japanese attack on China in 1937, but received in return unfair treatment ever after. Though in 1950 he obtained a post at the University of Shanxi province, for political reasons he was never able to write about his main research topic. During the Cultural Revolution he was severely attacked and even beaten. Later, bearing this burden, he kept quiet for the rest of his life. It is a pity for China and Chinese historiography that under repression he so early ceased to write. Only recently, long after his death, his son gathered his papers concerning Jesuit missionaries in Beijing, including Hallerstein, and published them in 2003 (Yan 2003).

The presence of all implications concerning the changes in the late Qing dynasty in China and the pressure of ideology on Chinese historic writing therefore demands a more thorough study of historic facts about Jesuits working in China from the times of Emperor Qianlong on and a new description of their historic role based upon documents and facts. Among other related topics an important issue is the necessity of rediscovering the appropriate historic role of Hallerstein in China. This process has begun with the endeavours of Professor Ju Deyuan, who published his first article in 1985 (Ju 1985). His work was later supported by the researchers of The First Historic Archive in Beijing and several other scholars in China, so we may hope that eventually a more accurate presentation of Hallerstein's deeds and his contribution to cultural exchange between Europe and China will appear in Chinese history books.

The rediscovery of Hallerstein's historical importance gained momentum in 2003 when the museum in his birthplace Mengeš started an initiative to mark the 300th anniversary of his birth. The museum organised a symposium in Ljubljana where several researchers and Slovenian sinologists joined endeavours to bring to light several aspects of Hallerstein's historic and scientific achievements. At this occasion a compendium of articles and translations of Hallerstein's letters was published (Hribar 2003), and another book by Professor Stanislav Južnič on Hallerstein's astronomic work (Južnič 2003). These activities promoted Hallerstein into the focus of Slovenian academic and cultural circles, and as a manifestation of his astronomic and scientific prominence even a celestial body, discovered by Slovenian astronomers, was named after him.

Researching Hallerstein's life in Beijing became a new challenge for Slovenian sinologists with the aim of discovering more materials about his life in Beijing, because until then almost no relevant Chinese documents were known. The other goal is to bring Hallerstein back to his historic position alongside the other great Jesuits of the Qing dynasty, where he belongs. The first step in this direction was at the 16th conference of the European Association of Chinese Studies (EACS), 
which was held in Ljubljana in August 2006, and where a round table on Jesuit Studies was dedicated mainly to the role of Augustin Hallerstein. Many European and several Chinese sinologists attending this round table believe that he is important for sinologists and cultural historians all over the world and especially for Slovenia, Austria, Portugal, and Russia these being the four countries to which he is most related.

A new step towards wider recognition of Hallerstein's historic role and his contribution as an early cultural bridge between Europe and China was the European Union project on cultural dialog between Europe and China, dedicated to the cultural role of Hallerstein's sojourn in China. The project lasted from 2007 till 2009 and was partly focused on artistic promotion of Hallerstein in several European countries as well as in China, though at the same time it also stimulated research on related topics. The results of the research were presented on symposiums and conferences in Portugal, Austria, Slovenia, and China. Especially significant was the International Symposium on "The Early European Missionaries Coming to China and Sinological Studies", which took place in Beijing at Beijing Language and Culture University on September, 26-27 2009 and had special focus on Hallerstein. This was the first time that an international discussion on Hallerstein had taken place in China and its importance is in the fact that it brought together a wider range of Chinese scholars from various research institutions that became interested in the research of this forgotten missionary, thus marking a new start in rediscovering Hallerstein's historic role in China.

The final deed of the above mentioned EU project is the publishing of the compendium on the life and work of Augustin Hallerstein titled: A. Hallerstein - Liu Songling: Multicultural Legacy of Jesuit Wisdom and Piety, published by KIBLA, Maribor 2009 and translated to Chinese in 2015. It is the first comprehensive publication appearing in English and covering a wider range of contents from his biography, a part of his scientific work, the updated state of research in China with the latest-discovered extant documents, to the full translation of most of letters discovered so far (excluded are only some purely scientific ones). This for the first time presented to the general global public the possibility of getting to know a more elaborate picture of this important missionary of the late Qing dynasty. In addition to the English translation of Hallerstein's letters, there is the English translation of Professor Šmitek's study of Hallerstein's biography and an article by Professor Južnič on Hallerstein's scientific engagement in the field of electrical and vacuum research. Since Hallerstein's scientific work is not the principal content of this book, the article on electrical and vacuum research illustrates only one small part of Hallerstein's scientific work. Nevertheless this field of science was among the most advanced in the scientific research of the time, demonstrating 
that Hallerstein as well as other Jesuit missionaries in Beijing were, apart from their astronomic engagement, also taking part in up-to-date scientific research. Finally Professor Ju Deyuan's article presents how he started to unveil the facts about Hallerstein's presence in the high ranking position in Beijing from Chinese documents, and then sums up the results of the research of historic facts concerning Hallerstein's life and work in China.

After the EU project and the above-mentioned symposium in Beijing the situation in China has also been gradually changing. The researchers of The First Historic Archive in Beijing are systematically searching for new documents related to Hallerstein and so far, more than fifty Qing dynasty documents about his activities have been discovered. This is a long term endeavour because out of the enormous amount of dynastic documents only a small portion has been evidenced and analysed. In the academic field researcher of several academic and cultural institutions like Chinese Academy of Social Sciences, The Palace-Gugong Museum and the Sinology Institutes of various Chinese universities, etc. are increasingly interested in Hallerstein's role in the Qing dynasty court. Then Hallerstein's name connected with Slovenia as the place of his origin has appeared in some important historic places like the Old Beijing Astronomic Observatory, the South Church, and the old Jesuit cemetery in Beijing. It is somehow a lucky coincidence that among many old Jesuit gravestones, of which more than half were completely or partially destroyed during the Boxer Rebellion in 1900 or later in the times of Great Cultural Revolution, Hallerstein's gravestone remained almost intact with well-preserved Chinese and Latin inscriptions, and is now standing in the newly adapted Jesuit memorial park in the location of the old Jesuit cemetery. However, up until now, probably the most influential event in the course of restoring Hallerstein's image and significance in China was the publication of the Chinese translation of the book A. Hallerstein - Liu Songling: Multicultural Legacy of Jesuit Wisdom and Piety at the Qing Dynasty Court in 2015 with Chinese title: Siluoweniya zai Zhongguo de Wenhua Shizhe - Liu Songling 斯洛文尼亞在中國的文化使者一劉 松齡 (A. Hallerstein, the Slovenian Cultural Envoy to China). Certainly, this book offers many data and a sound basis for Chinese historians to evaluate his cultural and scientific achievement and restore his historic position in Chinese history, with all relevant evaluations as such a prominent figure deserves. In addition, his letters and comments are also important for another insight into Chinese history of the time, so we may hope that after the publication of this book in China all major aspects of his work will be reassessed by Chinese historians. On the other hand there was a new initiative to popularise the awareness of his historic and cultural achievements among younger and general public by Slovenian Chinese artist Wang Huiqin 王慧琴 through the writing and illustration of a bilingual 
book: Slovenian Astronomer in the Forbidden City, which was published in a Chinese-Slovenian version in Ljubljana and in a Chinese-English version in Beijing. Very important aspects of Hallerstein's work were his cultural and diplomatic achievements, which have been almost completely overlooked in the past. Probably the most important diplomatic task accomplished with full success was his role of counsellor and intermediary during the Portuguese diplomatic mission to Beijing in 1753, led by the royal envoy Francisco de Assis Pacheco de Sampayo. In 1752 the emperor Qianlong appointed Hallerstein to escort the Portuguese King's envoy from Canton to Peking and back. So he travelled twice to Canton and back, which all together took him more than a year. Some important facts concerning Hallerstein's escort of the Portuguese King's Envoy to China from Canton to Peking and back to Macao were also found in the Library of the Imperial Palace. This mission was very successful and at the end the Emperor was very pleased, though not everybody in the Chinese court was happy that Hallerstein had been appointed to escort the Portuguese envoy. It was very much due to the Emperor's personal support that the mission was accomplished according to Hallerstein's plan. In a letter dated 21 October 1753, addressed to his brother, he wrote:

Your Eminence knows already from elsewhere that the Portuguese court sent a delegation to the Chinese Emperor. As the weather was favourable, it arrived in Macao in August of last year, that is, 1752. On October 2 I received a letter from the delegation, in which they explained the purpose of their mission to me and asked me to come to Macao personally to receive the delegation and led it to Peking. I have added to my letter a letter from the most illustrious Portuguese Queen Mother, with which she deigned to recommend me. From the letters of some of our other colleagues, I have discerned that this was the wish of the most illustrious and most pious king himself. The Emperor has just now left for Tartary so that he, as is his habit, can devote himself to the hunt. I had proposed the matter verbally as well as in written form to the official who is responsible to the Emperor for our affairs. I told him that it is the ambassador's wish that I personally go to meet him and lead him to Peking. He responded that it was indeed necessary that I go there in person. In a letter, to which he added my letter, he explained everything to the Emperor. The Emperor, who already before had desired this mission, as it would further his own favour, was extremely delighted by this news. He did not await the report of the prefects or the Cantonese mandarins-for which they are rather angry with me-and he did not even heed the opinion of the office to which matters of this sort belong, but decided 
that I should travel immediately to Macao and lead the mission and all of its entourage to Peking. And so I travelled from Peking on 25 October, 1752 in the company of a Tatar mandarin. We travelled now over dry land, now by rivers, at the ruler's expense and on his horses and ships. On December $13 \mathrm{I}$ arrived in Macao after fifty days of safe and swift travelling. This journey was the reason why I did not send a single letter to your Eminence last year, as I was underway precisely at the time I would have to have been writing it. Except for my letter to the most illustrious Queen there was no time for any others. When the ambassador, after he had seen to all necessities, was ready to travel, we set sail from Macao on December 20, since both he and the Emperor were eager. (Pray 1781, 3: XXIX-XXXII)

The Portuguese mission was a rare success. It succeeded in a time when all other attempts by Europeans to establish high-level contacts in China had failed. Hallerstein attended all the receptions, where he was also the main translator. He translated the emperor's letter to the king of Portugal as well and we may conclude that success was mainly due to Hallerstein's meticulous preparations and his diplomatic skill. A direct consequence of the mission was the improved position of Portuguese missionaries in Beijing with better working conditions. It was great diplomatic achievement that both sides were satisfied with the results of the mission, and so after the mission had been completed the emperor granted Hallerstein the title of official (mandarin) of the 3rd rank. In a letter from Canton to his brother Weichard dated 21 October 1753, Hallerstein described the reception in Beijing and the conclusion of the mission with these words:

After one hundred and thirty-four days of travel we arrived in solemn fashion in Peking on May 1. In these places I have never seen festivities of the like. We lingered there for thirty-nine days, entirely in accordance with custom. On June 8 the ambassador left Peking, and I with him. After one hundred and twenty-one days we returned to Macao on October 6. The reason for the long journey was that with such accompaniment and such a load one could not progress over dry land without great costs, travails and the perils of illness. For this reason we had to detour over longer, albeit more comfortable, river paths. (Pray 1781, 3: XXIXI-XXXII)

An important part of Hallerstein's cultural and diplomatic contribution towards better understanding between Europe and China were his letters as well as his contacts with the most prominent academies of science in Europe. Hallerstein maintained rich correspondence with other Jesuits in Europe during all the years 
of his life in China. In this correspondence, especially interesting from the point of cultural dialog are the letters to his brother Weichard and his sister Ann. In these letters he wrote about life in China, his position at the court, his relations with Emperor Qianlong, the position of the Christian church in China, and the problems of missionary work. Hallerstein's diplomatic activities were not limited to striving for better relations between the emperor and the Portuguese mission, to which he belonged, but also included securing good workable relations with the French mission, since tensions often appeared between the two, and establishing relations with the Russians. In Peking he often had the opportunity to meet Russians who were staying there or coming to China on various kinds of missions. He was aware of the conflicting situations which sometimes emerged between Russians and the Chinese and consequently even he happened to come in the middle of those tensions. In his letters he often mentions his own position in between Russians and the Chinese because of his good contacts with Russians. Apart from that he also makes observations about Russians staying in Peking, and describes their relations with Chinese authorities. For example in the letter to his brother dated 6 October 1743, he wrote about Russians living in Peking and about the messenger who came that year from Russia to announce the enthronement of the new tsarina. He writes: "I believe that already last year I wrote your Eminence that a caravan of Russians, as such are called, had arrived here and after an approximately six-month stay returned (home)."

Under the Emperor Qianlong the Russians and the Chinese agreed that such may come to court every three years to do business. They trade with various types of pelts. It is unusual that European dress seems so comical to the Chinese. They dress as we Germans do. They have a house which our ruler allotted them in which they all live when they come here to do business: some of their priests and clerics, currently three of them, are living here permanently, and there are just as many young men among them learning both the Chinese and Tatar languages in order to work as translators either at the Russian court or at the border.

They are soon expecting three more young men from Russia, of whom none is likely older than twenty, and who know Latin. Those who are now to return have been here ten or twelve years and have learned both languages well. This year a messenger from Russia arrived, who announced the ascension to the throne of the new Empress; from Petersburg to here took him three months. When he returned our ruler wanted to entrust him with gifts to take to the new Empress. Because they were too modest-consisting of twenty rolls of silk, called damascene, and twenty smallish, as well as just as many fairly large pots crafted merely of porcelain-he did not accept them, providing the excuse that he himself did not bear anything and that he thus did not dare take anything away, especially since the 
Empress had not commanded anything of that sort. When the Emperor forced him to take it nonetheless, he resisted all the more and took nothing. Because of this a conflict arose between him and the court, such that we did not dare visit him for fear his insistent rejecting or stubbornness would encumber us, since the Chinese and Tatars are very inclined to such suspicions. It would probably not be out of place to add at this point that we have here an office or dicastery-which they call lifanyuan, meaning court-which is responsible for foreigners. Its role is to deal with foreign arrivals and their affairs. All foreigners are subject to it, except for those of us Europeans who are not directly accountable to the Emperor. The concept of foreigners encompasses primarily foreigners from the north, Mongolians, Khalthas, Eleuts, Xifans, Russians and various other Tatars. Because in the beginning the Russian rulers themselves wrote letters to our ruler, while our ruler is not in the habit of writing personally or answering to anyone under the heavens, they arranged as a consequence that the Petersburg ruler write to the lifanyuan office, and that it might reply to them. (Pray 1781, 1: I-XVI)

\section{Hallerstein's Relations to Korea}

Apart from cultural links between Europe and China, Hallerstein also played a role in cultural and scientific exchange with Korea. In his letter to his brother Weichard he writes that Koreans came to Beijing every year and that immediately after arrival they come to the house of the Jesuits. They often pose well-founded questions about astronomy, always in written form, because they do not know how to speak Chinese, so they communicate in writing and the missionaries answer them through a servant. Hallerstein also mentions that Koreans are strong, muscular, well-built people, and good soldiers, and that they dress according to ancient Chinese customs. (Pray 1781, 4: XXXIII-XXXVII)

Among Chinese written materials I discovered an interesting description of a Korean visit and conversation with Hallerstein, which is included in a report of a member of the Korean mission to China (Hong 1998). The report is written in Classical Chinese and gives a description of the South Church and even a personal description of Hallerstein. This is the only description of his personal appearance that we have so far and it says that being 62 years old, he is healthy looking man with deep and sharp eyes, a grey beard and Chinese style hair with shaved front of the head and a long plait, dressed in the formal dress of Chinese official. On the 7 th day of the 1 st month ${ }^{2}$ the Korean emissary arrived to the South church, where Hallerstein received him and wrote that out of respect to the old man he

2 According to the Chinese lunar calendar in the year 1765 . 
did not dare to talk in loud voice. He describes the place and tells that Hallerstein led him to the upper floor, where he admired the organs, which he describes in detail and quotes the conversation with Hallerstein about music. Then Hallerstein led him down to the main hall and showed him the statue of the Lord of Heaven and the altar, and then around the church where he mentions the clock and the frescos. Then the Korean emissary came again on the 13th day but was told that the Reverend Hallerstein was out on duty, and that he should come again on the 19th. So on the 19th day he came again and was told that the master was at the observatory during the night and went to bed in the morning. He was asked to wait and was asked as to the reason for his visit. The answer was that he came to talk about astronomy. After presenting some gifts he was asked to put questions in written form. Asked about new calculations concerning the calendar, Hallerstein answered that in the old Chinese calculations there were many mistakes which the Jesuits were correcting, and preparing a new report for the Emperor, but their work had not yet been finished. At his request to see it, Hallerstein brought one manuscript in western script, furnished with drawings, and written so elegantly that it looked as if it had been printed. After some questions about the chiming clock and the armillary sphere instrument, neither, unfortunately, accessible to the visitors as the chiming clock was in the emperor's palace and armillary sphere was on the terrace of the Beijing observatory, the Korean emissary asked about the bearing compass and whether it was divided into 32 zones. Hallerstein answered that compasses had different divisions with $8,16,24$, or 32 zones, and that those with 32 zones were used for navigation. Asked about other instruments, Hallerstein showed the emissary an approximately meter-long bronze telescope with two lenses. The emissary admired the instrument and after looking at the sun asked how it was that the three dark sunspots were not visible. Hallerstein explained that sometimes there were up to eight sunspots but their number was not constant. Asked about other instruments Hallerstein answered that all the big instruments were at the observatory and then showed him another small instrument and a piece of paper with a star chart. After receiving some very humble gifts the Korean emissary left the residence of Jesuits at the South Church.

This description was written in classical Chinese and published in China under his Chinese name Hong Darong 洪大容. Only later did I discover his identity with the Korean name Hong Dae-yong. He was a scholar of Neo-Confucianism in Korea. In 1765 he followed his uncle Hong Eock on his mission to Imperial China. As an astronomer he was very interested in Jesuit astronomic measurements and calendrical calculations. The problem was that the Chinese were officially publishing the transcriptions of more than 200 years old Chinese measurements, which by the time were in significant discrepancy with the real situation. 
For this reason they in practice relied on Jesuit measurements, which were much more accurate. The Koreans were making their own measurements and they discovered that there were differences with what the Chinese were officially publishing so they were very curious to learn how the Jesuits were conducting their measurements and calculations as well as to prove that their own measurements had sound basis. This led to Hong Dae-yong's visits to the Jesuit mission in Beijing and to his encounters with Hallerstein. Hong Dae-yong wrote many books in classical Chinese and in Korean, among them a book based on his encounters, where he chronicles his meetings with Hallerstein. He is now regarded as a major literary figure of the 18th century. This travelogue-the rough translation of the title would be Questions put to Yu and Some Answers - is regarded as one of the three finest of that time, and through this book Hallerstein became rather well known in Korea. As Hong Dae-yong was also a social reformer and a champion of European enlightenment, the descriptions of his encounters with Hallerstein are fascinating, and so we hope to obtain a translation sooner or later.

In the entire Qing dynasty there were only four European Jesuits who received higher ranks than Hallerstein. These were: Adam Schall von Bell, 1st rank, and Ferdinand Verbiest, Ignatius Kögler, and Felix Da Rocha, all of them 2nd rank. Hallerstein succeeded the post of head astronomer after the death of Ignatius Kögler in 1746 and held it continuously until his death in 1774 . He was a top-ranking scientist of the time and maintained contacts with the Academies in London, Paris, and Saint Petersburg, and had a very high position under the emperor Qianlong. Against all odds and tensions he succeeded in keeping the position as head of the Imperial Board of Astronomy for the longest term in history, lasting 28 years. In this position he acted as an important cultural link of the time between China and Europe and is interesting for Europeans as well as for Chinese. Hallerstein died just one year after Pope Clement XIV dissolved the Society of Jesus, though the Jesuits in Peking kept working as court astronomers even after that event. A particularly interesting situation is the coincidence of this event and his death. We know that the Pope dissolved the Jesuit order in 1773 and that Hallerstein died about one year later on 29 October 1774. It is also known that the news of the dissolution of the Jesuit order reached Beijing on 5 August 1774 (Vissière 1979), so Hallerstein must have heard the news about the dissolution of Jesuit order before his death. In this connection we may conclude that this shock accelerated the deterioration of his health and led to his death some three months later. Hallerstein was buried in the Jesuit cemetery in Peking, where his gravestone is preserved in the memorial park together with other great Jesuit missionaries. Our intention is to illuminate his deeds, opinions, and merits in order to place him into historic context next to other famous Jesuits of the Qing dynasty. 


\section{Conclusion}

With the aim of exposing his historic significance we started a new initiative in co-operation with Slovenian State Archive in 2012 to make a replica of Hallerstein's most outstanding astronomic instrument, the equatorial armillary sphere, and install it in a suitable place in Ljubljana as a monument to his scientific achievements and early cultural contacts between Slovenia and China. The initiative received support from the Slovenian Academy of Sciences, University in Ljubljana, Slovenian Ethnographic Museum, as well as from wider cultural and political circles in Slovenia. The idea was to engage the Chinese side to produce a replica of the instrument by a gesture of good will and to present it to Slovenia as a symbol of our early contacts and co-operation. With its visual appeal and symbolic significance it could gradually became a strong mark of the long history of friendly relations between China and Slovenia and a reminder of Hallerstein's historic importance to the broader Slovenian public, visitors from China, as well as for tourists visiting Ljubljana. The fact that in Leuven in front of the Verdinand Verbiest Institurte in the complex of Leuven University there is a replica of Verbiest's astronomic instrument from Beijing, the celestial globe, which the Chinese delivered to Belgium in 1989 and which has since then served as a strong symbol of friendly relations is ample confirmation that this idea is realistic.

\section{References}

Chevalier, S., and P.Tsuchihashi, trans., eds. 1914. Observatotire de Zi-ka-wei: Annales de'l observatoire astronomique, Tome VII, anne 1911. Chang-hai (Shangai).

Ju, Deyuan 鞠德源. 1985. “Qing Qintianjian jianzheng Liu Songling - jinian Nansilafu tianwen xuejia Liu Songling shishi erbai yishi zhounian 清钦 天监监正刘松龄一纪念南斯拉夫天文学家刘松龄逝世二百一十周年.” Gugong bowuyuan yuankan 故宮博物院院刊 1: 53-62.

Hong, Darong 洪大容. 1998. “Liu Bao Wenda 刘鲍问答.” In Dong xi jiaoliu shi lungao 东西交流史论稿. Shanghai: Shanghai guji chuban she.

Hribar, Viljem Marjan, ed. 2003. Mandarin: Hallerstein, Kranjec na kitajskem dvoru. Radovljica: Didakta.

Južnič, Stanislav. 2003. Kitajski astronom iz Mengša. Ljubljana: Tehniška založba. Keller, Franz, ed. 1755. Der Neue Welt-Bott. Book IV, Part XXX. Vienna. ed. 1758. Der Neue Welt-Bott. Book IV, Part XXXIV. Vienna.

Osojnik, Jani. 2003. "Avguštin Hallerstein in knjiga Astronomski opazovalnik in popolne študije po nalogu cesarja." In Mandarin: Hallerstein, Kranjec na kitajskem dvoru, edited by Viljem Marjan Hribar, 191-210. Radovljica: Didakta. 
Pfister, Louis. 1934. Notices biographiques et bibliographiques sur les Jésuites de l'ancienne mission de Chine 1552-1773. II. Chang-hai: Imprimerie de la Mission Catholique.

Pray, György. 1781. Imposturae a.CCXVIII in dissertatione R.P.Benedicti Cetto, Clerici Regularis a Scholis Piis de Sinensium Imposturisdetectae et convulsae. Budae.

Saje, Mitja, ed. 2009. A. Hallerstein - Liu Songling: The Multicultural Legacy of Jesuit Wisdom and Piety at the Qing Dynasty Court. Maribor: Association for Culture and Education Kibla; Ljubljana: Arhiv Republike Slovenije.

Šmitek, Zmago. 1986. Klic daljnih svetov. Radovljica: Didakta.

—. 1995. Srečevanja z drugačnostjo: slovenska izkustva eksotike. Radovljica: Didakta.

Vissière, Isabelle, and Jean-Louis. 1979. Lettres édifiantes et curieuses de Chine par les missionnaires jésuites, 1702-1776, chronologie, introduction, notices et notes. Paris: De l'Université de Provence, Garnier-Flammarion.

Yan, Zonglin 阎宗临. 2003. Chuanjiaoshi yu Faguo zaoqi Hanxue 传教士与法国 早期汉学. Zhengzhou: Daxiang chuban she. 